\title{
Penerapan Low Impact Development (LID) Untuk Meminimalisir Genangan
}

\author{
Yang Ratri Savitri \\ (Institut Teknologi Sepuluh Nopember) \\ yangratrisavitri@gmail.com
}

\begin{abstract}
Abstrak - Institut Teknologi Sepuluh Nopember ( ITS ) merupakan salah satu kampus yang eco lingkungan berada di Surabaya bagian timur. Luas area keseluruhan $\pm \mathbf{1 8 0}$ ha yang terdiri dari bangunan, fasilitas umum dan ruang terbuka hijau. Berdasarkan kondisi eksisting saat ini, banyak lahan kosong yang nantinya akan dikembangkan sesuai dengan rencana Master Plan. Dengan adanya pengembangan tersebut akan mengubah lapisan tidak kedap yang awalnya dapat dimanfaatkan sebagai tampungan sementara atau sebagai daerah resapan maka akan berubah menjadi kawasan kedap. Perubahan tersebut akan mengakibatkan limpasan air hujan yang semula jatuh pada lahan kosong tersebut, sebagian akan meresap ke dalam tanah dan selebihnya dialirkan menuju saluran di sekitar. Maka, dengan adanya perubahan lapisan menjadi kedap akan memberikan dampak limpasan air hujan semakin besar untuk dialirkan menuju saluran drainase. Pada saat musim hujan, masih banyak terjadi genangan di beberapa tempat yang disebabkan oleh beberapa permasalahan diantaranya adalah saluran drainase yang belum terintegrasi dengan saluran bagian hilirnya sehingga air tidak dapat mengalir menuju pembuang akhir, kondisi street inlet yang tertutup oleh tanah dan sampah di beberapa lokasi mengakibatkan air hujan yang jatuh di jalan tidak dapat masuk ke saluran drainase, kapasitas saluran drainase yang kurang memenuhi, dll. Dengan adanya pengembangan kawasan, diharapkan tidak menambahkan beban seperti permasalahan yang telah diuraikan sebelumnya. Pada penelitian ini, akan dilakukan simulasi terhadap pengembangan kawasan dengan menerapkan Low Impact Development (LID). Proses simulasi akan dilakukan dengan menggunakan program bantu Storm Water Management Model (SWMM), dimana didalamnya terdapat beberapa alternatif LID yang dapat diterapkan dalam pengembangan kawasan. Dari hasil simulasi yang telah dilakukan, dengan menerapkan LID untuk beberapa tipe diantaranya adalah green roof dan permeable pavement untuk menurunkan debit limpasan.
\end{abstract}

Kata Kunci : drainase, genangan, low impact development, SWMM

sistem drainase. Diharapkan dengan adanya hasil dari studi tersebut dapat dijadikan sebagai pertimbangan dalam perencanaan sistem drainase ke depan. Dalam hal pengembangan kawasan, hal lain yang juga dapat dijadikan pertimbangan adalah dengan menerapkan konsep Low Impact Development guna menunjang eco lingkungan. Pada penelitian ini, akan dilakukan simulasi penerapan konsep tersebut untuk diketahui seberapa besar pengaruh penurunan debit limpasan di dalam kawasan kampus. Proses simulasi akan menggunakan program bantu Storm Water Management Model (SWMM) yang terdiri dari beberapa macam tipe LID.

\section{METODE PENELITIAN}

Studi genangan Kampus ITS ini akan dilakukan dengan mengimplementasikan software EPA Storm Water Management Model ( SWMM ) untuk mengetahui kondisi saluran drainase berdasarkan debit limpasan air hujan. SWMM merupakan model simulasi dinamik hujan - debit yang digunakan untuk simulasi single atau long term dari kuantitas dan kualitas debit limpasan air hujan terutama untuk daerah perkotaan. Proses penelitian akan dilakukan melalui beberapa tahap 
seperti ditunjukkan dalam bagan alir penelitian pada Gambar 1.

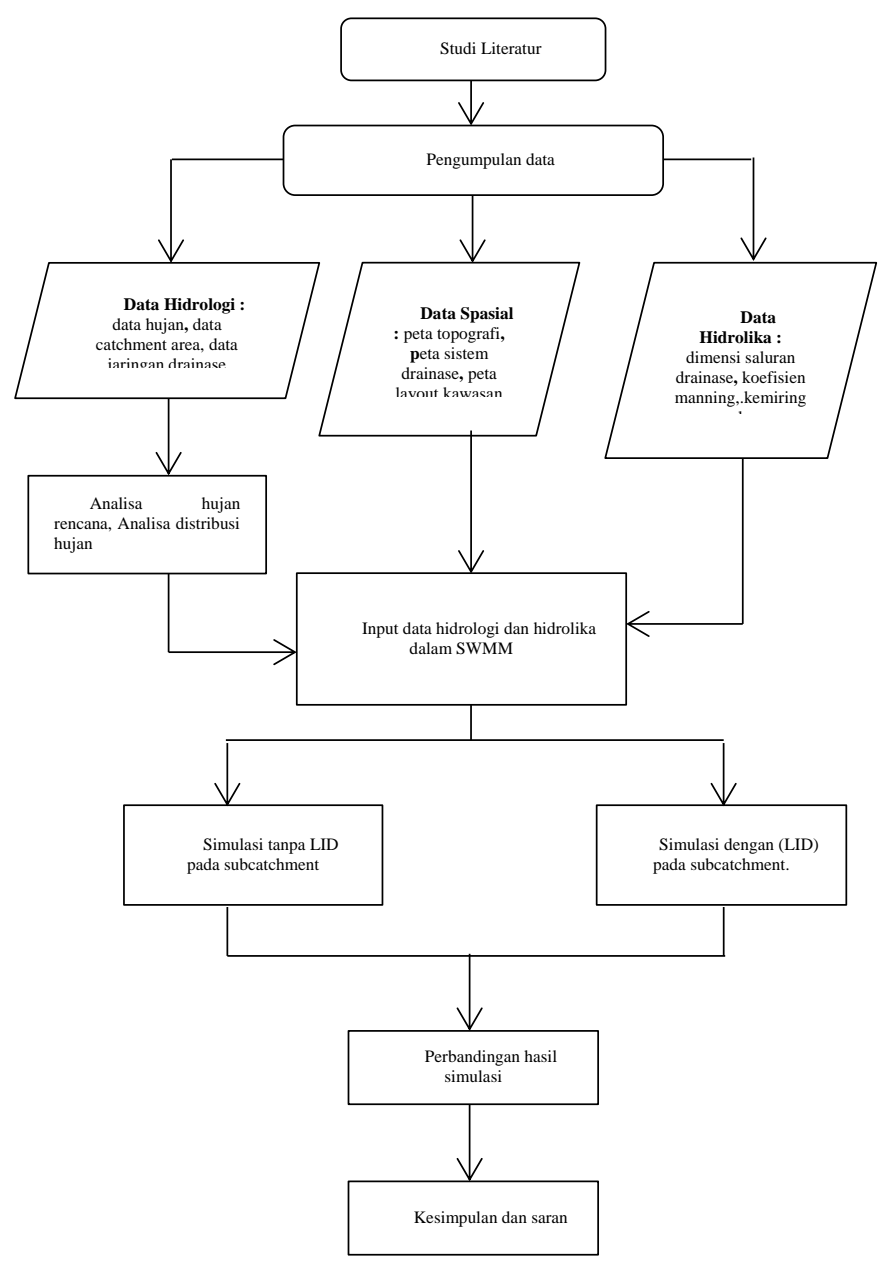

Gambar 1 : Bagan Alir Penelitian

\subsection{Studi Literatur}

Studi literatur yang dilakukan dalam laporan penelitian ini adalah tinjauan pustaka terhadap studi terdahulu yang pernah dilakukan serta layout master plan dari kampus ITS. Studi literatur tersebut merupakan bahan pertimbangan dalam menentukan alternatif yang digunakan dalam simulasi model. Berdasarkan studi literatur tersebut juga dapat diketahui identifikasi awal terhadap permasalahan genangan yang terjadi di lokasi studi. Selain itu, dalam tahap ini juga dilakukan pengumpulan data hidrologi dan hidrolika yang diperlukan dalam proses simulasi. Data tersebut merupakan data sekunder yang diperoleh dari dinas terkait.

\subsection{Identifikasi Permasalahan}

Identifikasi permasalahan pada tahap sebelumnya perlu dievaluasi kebenarannya dengan cara melakukan survey di lapangan. Survey tersebut bertujuan untuk meninjau secara langsung mengenai permasalahan yang diperoleh dari hipotesa awal. Dengan adanya identifikasi permasalahan, maka dapat ditentukan langkah yang harus dilakukan dalam penelitian ini, dalam hal ini adalah analisa beserta data yang diperlukan untuk menunjang proses simulasi model.

\subsection{Pengumpulan Data}

Data yang diperlukan dari simulasi model ini adalah data hidrologi, data hidrolika dan data spatial. Ketiga data tersebut akan digunakan sebagai input data dalam pembuatan model, berikut murapakan uraian dari beberapa data yang diperlukan dalam proses simulasi. yaitu :

\section{Data Spasial}

Data spasial yang diperlukan dalam pembuatan model ini adalah data layout kampus ITS (layout master plan) dan data peta topografi. Data layout akan digunakan sebagai pedoman dalam melakukan survey pengukuran saluran drainase serta background map dalam model swmm untuk menentukan pembagian subcatchment, node beserta link dalam simulasi.

\section{Data Hidrologi}

Data hidrologi digunakan untuk menentukan besarnya debit limpasan yang mengalir menuju saluran drainase. Dalam prosesnya, perhitungan debit limpasan tersebut memerlukan besaran hujan rencana dan distribusi hujan terpusat. Selanjutnya hasil perhitungan tersebut digunakan sebagai input data dalam model. Data hujan diperoleh dari pencatatan stasiun terdekat yaitu stasiun hujan Keputih. Data lain yang juga diperlukan dalam proses simulasi adalah luas lahan, tata guna lahan, dan jaringan drainase.

\section{Data Hidrolika}

Data hidrolika dalam penelitian ini adalah data terkait penampang saluran drainase yaitu potongan melintang dan memanjang saluran drainase. Berdasarkan data potongan melintang akan diketahui dimensi penampang dari saluran drainase, sedangkan pada potongan memanjang akan diperoleh kondisi kemiringan dasar saluran. Kedua data tersebut juga telah merepresentasikan elevasi dari saluran drainase. 


\subsection{Analisa dan Simulasi Model}

Pada penelitian ini terdapat beberapa macam analisa yang perlu dilakukan yaitu perhitungan hujan rencana, perhitungan distribusi hujan terpusat, dan proses simulasi dengan program bantu SWMM (Storm Water Management Model). Simulasi akan dilakukan untuk dua kondisi yaitu eksisting dan alternatif pengembangan. Simulasi kondisi eksisting ditentukan berdasarkan hasil survey di lapangan. Dari hasil simulasi akan diperoleh besarnya surface runoff dan final stored pada subcathcment berdasarkan kondisi eksisting. Sedangkan simulasi alternatif dilakukan dengan menerapkan konsep LID (Low Impact Development) pada subcatchment. Tujuan dari penerapan konsep tersebut adalah kawasan yang terbangun dengan adanya pengembangan kampus ITS tetap memberikan kesempatan limpasan permukaan untuk dapat meresap ke dalam tanah sehingga beban debit limpasan yang masuk ke saluran drainase tidak terlalu besar. Pada model SWMM, terdapat beberapa 7 tipe LID yang dapat diterapkan diantaranya adalah green roof, rain garden, rain barrel, bio retention, infiltration trench, permeable pavement, vegetative swale. Namun dalam simulasi tidak semua tipe tersebut diterapkan dalam subcatchment, pemilihan tipe akan didasarkan pada kondisi eksisting yaitu keberadaan bangunan dan kondisi lahan salah satunya adalah muka air tanah.

Hasil simulasi dari kedua model akan dibandingkan untuk menunjukkan pengaruh dari penerapan LID serta tipe manakah yang sangat mungkin diterapkan dalam pengembangan kampus.

\subsection{Kesimpulan dan Saran}

Hasil simulasi model akan memberikan pertimbangan mengenai konsep LID yang dapat diterapkan untuk pengembangan suatu kawasan yang mungkin dapat diterapkan pada kawasan lain dengan karakteristik yang sama.

\section{ANALISA DAN PEMBAHASAN}

Lokasi studi pada penelitian ini terletak di kawasan Kampus ITS seperti ditunjukkan dalam Gambar 2 : Lokasi Studi.

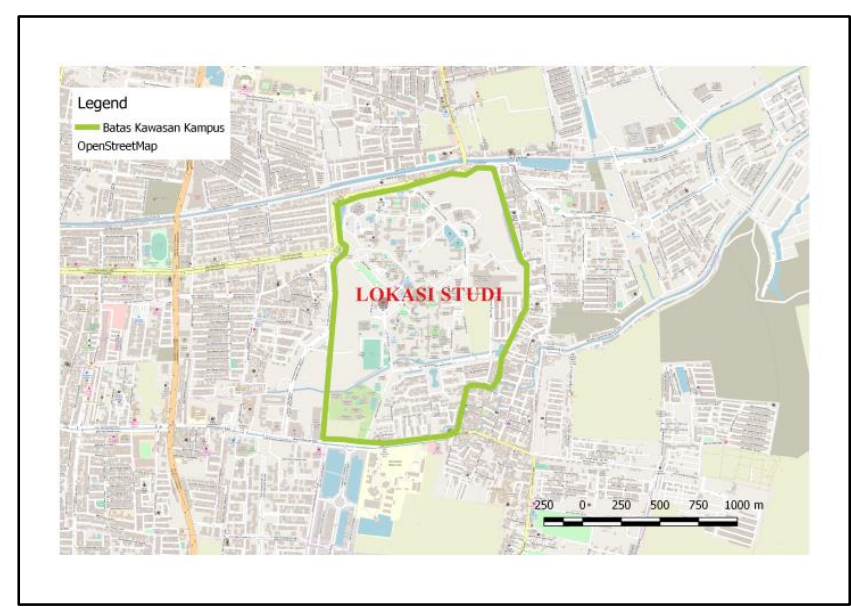

Gambar 2 : Lokasi Studi

\subsection{Simulasi Model}

Permodelan SWMM (Storm Water Management Model) ini merupakan kombinasi analisa hidrologi dan hidrolika. Sebelum melakukan input data dalam model, diperlukan analisa hidrologi terkait hujan sebagai input data dalam model. Berikut merupakan uraian dari proses yang dilakukan, yaitu :

\section{Analisa Perhitungan Hidrologi}

Analisa perhitungan, perhitungan yang dilakukan adalah perolehan besar hujan rencana untuk dijadikan input data dalam program SWMM.

Simulasi Model, simulasi model yang dilakukan dalam penelitian ini adalah simulasi data hidrologi dan hidrolika. Input data dari analisa hidrologi yang diperlukan adalah hujan rencana periode ulang yang kemudian diubah dalam bentuk distribusi hujan terpusat 5 jam. Data yang diperlukan untuk analisa hujan rencana periode ulang adalah data hujan harian stasiun hujan Keputih dengan hasil perhitungan hujan rencana adalah :

Tabel 1 : Hujan Rencana Periode Ulang

\begin{tabular}{|c|c|c|c|c|c|}
\hline Periode Ulang & LogXrt & \multirow{2}{*}{ Faktor Distribusi } & \multirow{2}{*}{ SLOGX } & LOGX & \multirow{2}{*}{$\mathbf{X}$} \\
\cline { 5 - 7 } tahun & $\mathbf{m m}$ & & & \\
\hline & & & & \\
\hline 2 & 2.03 & -0.18 & 0.14 & 2.00 & 100 \\
\hline 5 & 2.03 & 0.75 & 0.14 & 2.13 & 134 \\
\hline 10 & 2.03 & 1.34 & 0.14 & 2.21 & 162 \\
\hline & & & & & \\
\hline
\end{tabular}

sumber : hasil perhitungan

Hujan rencana periode ulang yang digunakan sebagai data input adalah hujan rencana periode ulang 5 tahun yang kemudian didistribusikan menjadi hujan terpusat selama 5 jam seperti ditunjukkan dalam Tabel 2. 
Tabel 2: Distribusi Hujan Terpusat

\begin{tabular}{|l|c|c|c|c|c|c}
\hline \multicolumn{1}{|c}{ jam ke } & $\mathbf{1}$ & $\mathbf{2}$ & $\mathbf{3}$ & $\mathbf{4}$ & $\mathbf{5}$ & $\mathbf{6}$ \\
\cline { 2 - 7 } & & & & & & \\
\hline Rata-rata hujan sampai jam ke & 68 & 43 & 33 & 27 & 23 & 0 \\
\hline Intensitas hujan pada jam ke & 68 & 18 & 12 & 10 & 8 & 0 \\
\hline
\end{tabular}

sumber : hasil perhitungan

$\checkmark$ Input data dalam model

Data input yang dimasukkan dalam model merupakan data hidrologi dan hidrolika. Data hidrologi akan dibagi menjadi beberapa macam yaitu data hujan dan subcatchment. Sedangkan data hidrolika terdiri dari node dan link. Berikut merupakan uraian dari masing - masing data, diantaranya adalah : 1. Data Hidrologi :

a. Rain Gage, merupakan input data hujan dengan beberapa tipe data yang dapat ditentukan yaitu dalam bentuk intensitas, volume dan kumulatif. Data tersebut disimpan dalam bentuk time series.

b. Subcatchment, merupakan input data terkait dengan lahan. Dalam hal ini, lokasi studi harus dibagi dulu menjadi beberapa subcatchment (Gambar 3 : subcatchment pada model). Beberapa input data yang diperlukan adalah outlet dari lahan tersebut, luas area, kemiringan lahan, prosentase impervious, subarea routing, dll.

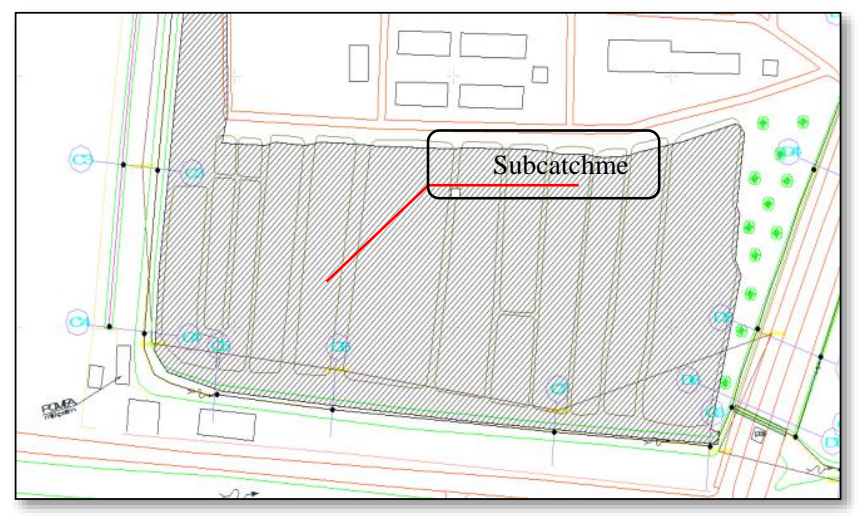

Gambar 3 : Subcatchment pada model

LID pada simulasi model diterapkan dalam subcatchment sesuai dengan tipe yang dapat diterapkan berdasarkan karakteristik masing - masing subcatchment.

2. Data Hidrolika :

a. Node

Beberapa input data yang diperlukan dalam node adalah junction, outfall, divider dan storage unit. Penggunaan tipe node tersebut tergantung dari bangunan air dalam sistem drainase. Junction dalam simulasi ini menggambarkan titik cross section yang dilakukan pengukuran, sehingga jumlah dan penamaan junction disesuaikan berdasarkan pengukuran. Input data pembuang akhir dalam simulasi ini ditentukan dengan menggunakan tipe outfall pada node. Jika dalam sistem drainase terdapat tampungan (storage area) sebagai pembuang akhir maka perlu melengkapi storage curve pada storage unit. Input data node dalam model ditunjukkan pada Gambar 4.

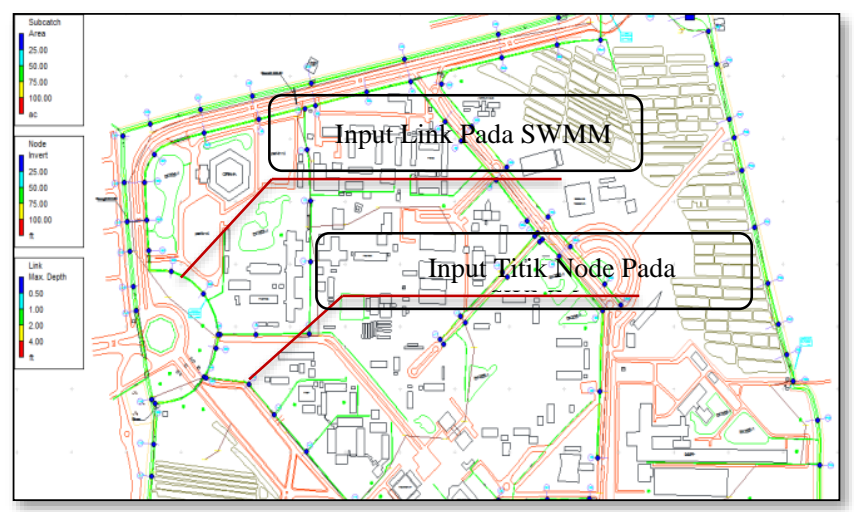

Gambar 4 : Node dan link pada model

b. Link

Data yang diperlukan dalam menu link pada SWMM ini merupakan dimensi penampang yang diperoleh dari hasil pengukuran. Terdapat beberapa macam data yang diperlukan selain data penampang yaitu fasilitas drainase yang terletak pada saluran misalnya pompa air, pintu air, dll.

\subsection{Hasil Simulasi}

Hasil simulasi dalam model dibedakan atas dua hal yaitu simulasi tanpa penerapan LID dan simulasi dengan penerapan LID. Berikut merupakan uraian dari kedua simulasi,yaitu :

Tanpa penerapan konsep low impact development (LID).

Simulasi kondisi eksisting dilakukan dengan tanpa penerapan konsep LID dalam subcatchment. Dengan asumsi bahwa pengembangan kawasan yang terjadi untuk beberapa tahun kedepan akan banyak merubah lapisan tidak kedap menjadi lapisan kedap. Berdasarkan peta SDMP 2018 (Surabaya Drainage Master Plan), terdapat beberapa subcatchment dari luar kawasan yang masuk dalam sistem drainase ITS. Subcatchment tersebut dalam simulasi ini akan diasumsikan memiliki perubahan terhadap lapisan tidak kedap menjadi lapisan kedap, sehingga akan berpengaruh terhadap nilai koefisien pengaliran. Berikut merupakan hasil simulasi dari model, yaitu: 
Tabel 3 : Resume hasil simulasi runoff tanpa LID

\begin{tabular}{lll}
\hline No & Keterangan & Volume hectare $-\mathrm{m}$ \\
\hline
\end{tabular}

\section{$\underline{\text { Runoff Quantity Continuity }}$}

\begin{tabular}{ccc}
\hline $\mathbf{1}$ & Total Precipitation & 730468.215 \\
$\mathbf{2}$ & Surface Runoff & 202239.954 \\
$\mathbf{3}$ & Final Surface Storage & 543185.147 \\
\hline
\end{tabular}

sumber : hasil simulasi

Tabel 4 : Resume hasil simulasi flow routing tanpa LID

$$
\text { No }
$$

Keterangan

Volume $\left(10^{6}\right.$ liter $)$

\section{Flow Routing Continuity}

\begin{tabular}{ccc}
\hline $\mathbf{1}$ & Final Stored Volume & 1021.960 \\
\hline sumber $:$ hasil simulasi &
\end{tabular}

sumber : hasil simulasi

$\checkmark$ Dengan menerapkan konsep low impact development (LID)

Pada simulasi yang kedua, dilakukan penerapan LID dalam subcatchment dengan beberapa tipe. Berdasarkan kondisi eksisting di lapangan, dengan beberapa pertimbangan terkait pengembangan dan karakteristik dari lahan maka tipe LID yang digunakan dalam model adalah rain garden, green roof, dan bioretention. Ketiga tipe tersebut diterapkan pada sebagian luas kawasan untuk masing - masing subcatchment. Berikut merupakan hasil simulasi model,yaitu :

Tabel 5 : Resume hasil simulasi runoff dengan LID

\begin{tabular}{ccc}
\hline No & Keterangan & Volume hectare $-\mathbf{m}$ \\
\hline \multicolumn{2}{r}{ Runoff } & Quantity Continuity \\
& \\
\hline $\mathbf{1}$ & Total Precipitation & 730468.215 \\
$\mathbf{2}$ & Surface Runoff & 58816.175 \\
$\mathbf{3}$ & $\begin{array}{c}\text { Final Storage } \\
\text { Surface }\end{array}$ & 652960.169 \\
\hline
\end{tabular}

sumber : hasil simulasi

Tabel 6 : Resume hasil simulasi flow routing dengan LID

No Keterangan

Volume

$\left(\mathbf{1 0}^{6}\right.$ liter $)$

\section{Flow Routing Continuity}

\begin{tabular}{cccc}
\hline $\mathbf{1}$ & $\begin{array}{c}\text { Final } \\
\text { Volume }\end{array}$ & Stored & 1021.962 \\
\hline
\end{tabular}

\section{KESIMPULAN}

1. Data yang digunakan dalam penelitian ini terdiri dari :

- Data primer, diantaranya adalah arah aliran, penampang melintang dan memanjang saluran drainase dalam sistem drainase ITS.

- Data Sekunder, diantaranya adalah data hujan harian, layout kawasan ITS, dan studi terdahulu.

2. Data hujan yang digunakan dalam penelitian pemula ini adalah data hujan dari pencatatan stasiun hujan Keputih.

3. Hujan rencana yang digunakan adalah hujan rencana periode ulang 5 tahun, yaitu $R_{5}=$ $134 \mathrm{~mm}$.

4. Berdasarkan hasil survey di lapangan, terdapat beberapa permasalahan dalam sistem drainase yang dijadikan sebagai pertimbangan dalam simulasi model, yaitu:

- Saluran drainase yang dipenuhi oleh tanaman liar sehingga mengganggu aliran air menuju pembuang akhir.

- Outlet saluran drainase yang dipenuhi oleh enceng gondok sehingga menghambat aliran menuju pembuang akhir.

- Kapasitas saluran drainase yang tidak sesuai dengan debit limpasan yang mengalir.

- Banyak outlet dari luar kawasan yang masuk ke dalam saluran drainase ITS, sehingga kapasitas saluran tidak lagi sesuai dengan catchment area yang dilayani sebelumnya.

- Terdapat outlet yang tidak dimungkinkan aliran air dilewatkan menuju outlet tersebut terkait dengan adanya konflik warga.

\section{SARAN}

Permasalahan genangan yang terjadi tidak hanya disebabkan oleh kondisi saluran drainase. Berdasarkan hasil survey di lapangan menunjukkan bahwa bahwa debit limpasan yang masuk pada sistem drainase kampus tidak hanya berasal dari dalam kawasan, namun juga dari kawasan lain yang berada dekat dengan lokasi kampus. Untuk dapat meminimalisir genangan, maka kondisi tersebut juga harus dikontrol dengan baik. Secara teknis, debit limpasan yang masuk dari luar kawasan perlu dikontrol menambahkan fasilitas drainase seperti pintu air. Kemudian untuk mengantisipasi penambahan debit limpasan akibat pengembangan, maka dapat diterapkan konsep LID seperti simulasi yang telah dilakukan. Berikut merupakan beberapa saran untuk mengurangi dampak genangan kondisi eksisting maupun setelah adanya pengembangan, yaitu : 
1. Pemeliharaan rutin pada saluran drainase beserta fasilitas drainase yang ada dalam kawasan kampus.

2. Mengintegrasikan seluruh saluran drainase dalam sistem hingga menuju pembuang akhir.

3. Melakukan perbaikan terhadap fasilitas drainase yang tidak berfungsi maksimal.

4. Merencanakan fasilitas drainase seperti pintu air untuk membatasi debit limpasan yang masuk dari luar kawasan pada saluran drainase barat Sehingga limpasan debit tersebut tidak masuk ke dalam saluran drainase tengah melainkan mengalir melalui saluran drainase barat ITS menuju pompa Mulyosari.

5. Normalisasi dasar saluran untuk lebih mengoptimalkan aliran menuju pembuang akhir.

6. Menambahkan pompa pada beberapa lokasi untuk membantu mengalirkan air pada kondisi mendesak.

7. Menerapkan green roof pada bangunan-bangunan eksisting yang dapat memberikan beberapa manfaat yaitu mengurangi suhu panas yang terjadi, memperpanjang waktu konsentrasi sehingga mengurangi debit limpasan yang masuk dalam saluran drainase.

8. Menerapkan rain garden pada beberapa area sebagai daerah resapan dari limpasan air hujan.

9. Menerapkan bio-retention pada beberapa lokasi yang dimungkinkan untuk meletakkan storage area. Akan tetapi, dalam menentukan lokasi bioretention perlu mempertimbangkan kondisi muka air tanah.

10. Menerapkan permeable pavement pada beberapa lapisan kedap, dengan memberikan storage pada bagian dasar dari pavement sebagai tampungan sementara serta memberikan saluran drainase (underdrain) untuk dapat mengalirkan air hujan dari storage menuju saluran drainase.

\section{DAFTAR PUSTAKA}

[1] "Storm Water Management Model Application Manual", EPA United States Environmental Protection Agency, 2009.

[2] "Tata Cara Penyusunan Rencana Induk Sistem Drainase Perkotaan", Kementerian Pekerjaan Umum Direktorat Jendral Cipta Karya, 2012.

[3] "Tata Cara Perencanaan Kolam Detensi, Kolam Retensi dan Sistem Polder", Kementerian Pekerjaan Umum Direktorat Jendral Cipta Karya, 2012.

[4] Anggrahini,M.Sc.," Hidrolika Saluran Terbuka", CV.Mitra Media, Surabaya,1997.

[5] Harto,Sri, "Analisis Hidrologi", PT. Gramedia, 1993.

[6] Kodoatie,Robert.J, "Rekayasa dan Manajemen Banjir Kota”, Andi, Yogyakarta, 2013.

[7] Soewarno, "Hidrologi untuk Statistik,jilid 1", Nova, Bandung, 1995.

[8] Soewarno, "Hidrologi untuk Statistik,jilid 2", Nova, Bandung, 1995.

[9] Subarkah, Iman,Ir.," Hidrologi Untuk Perencanaan Bangunan Air", Idea Dharma, Bandung, 1978.

[10] Sosrodarsono, Suyono,Ir.," Hidrologi Untuk Pengairan" PT.Pradnya Pramita, Jakarta,1978.

[11]Wilson,E.M," Hidrologi Teknik",ITB, Bandung, 1990.

[12] Yuwono, Nur,Ir.," Hidrolika 1", PT.Hanindita, Yogyakarta, 1977. 